\title{
Stimulasi Kecerdasan Naturalis Anak Usia 5-6 Tahun melalui Kegiatan Life Science
}

\author{
Angra Gumitri ${ }^{1 凶}{ }^{凶}$ Dadan Suryana ${ }^{1}$ \\ Pendidikan Anak Usia Dini, Universitas Negeri Padang, Indonesia(1) \\ DOI: 10.31004/obsesi.v6i4.2334
}

\begin{abstract}
Abstrak
Usia dini merupakan masa yang paling tepat dalam mengembangkan berbagai potensi yang dimiliki anak sejak lahir. Penelitian ini bertujuan untuk memberikan stimulasi terhadap kecerdasan anak terutama pada kecerdasan naturalis anak yang berusia 5-6 tahun. Penelitian ini menggunakan jenis penelitian kualitatif deskriptif. Populasi diambil secara acak atau random sampling. Sedangkan sampel yang diambil adalah anak yang berusia 5-6 tahun saja. Hasil dari penelitian ini menunjukkan bahwa pentingnya mengembangkan kecerdasan naturalis untuk anak usia dini karena masing-masing anak memiliki potensi berbeda. Kecerdasan tidak hanya terletak pada kemampuan otak saja. Namun masih banyak kecerdasan yang harus diberi stimulasi. Kegiatan life science sangat berdampak pada kecerdasan naturalis pada anak. Melalui kegiatan life science ini terlihat anak sangat menikmati dan bersemangat mengikuti proses pembelajaran serta anak menjadi tertarik untuk menjaga lingkungan sekitarnya dengan cara merawat dan membersihkan. Dengan adanya kegiatan life science ini membentuk kecerdasan terutama kecerdasan naturalis anak yang saat ini jarang diberikan stimulasi sejak usia dini. Hal ini sangat berkaitan dengan indikator pada kecerdasan naturalis pada anak usia dini.
\end{abstract}

Kata Kunci : kecerdasan naturalis; aktifitas life science; anak usia dini

\begin{abstract}
Early age is the most appropriate period in developing various potentials that children have from birth. This research uses descriptive qualitative research. This research aim is providing stimulation to children's intelligence, especially the naturalist intelligence of children aged 56 years. The population is taken randomly or random sampling. While the samples taken were children aged 5-6 years. The results of this study indicate that it is important to develop naturalist intelligence for early childhood because each child has different potentials. Intelligence does not only lie in the ability of the brain. But there is still a lot of intelligence that needs to be stimulated. Life science activities have an impact on naturalist intelligence in children. Through this life science activity, it can be seen that children really enjoy and are enthusiastic about participating in the learning process and children become interested in protecting the surrounding environment by caring for and cleaning. With this life science activity, it forms intelligence, especially the naturalist intelligence of children who are currently rarely stimulated from an early age. This is closely related to indicators of naturalist intelligence in early childhood.
\end{abstract}

Keywords: naturalist intelligence; life science activities; early childhood

Copyright (c) 2022 Angra Gumitri, Dadan Suryana

$\triangle$ Corresponding author :

Email Address : angra.gumitri@yahoo.com (Padang, Indonesia)

Received 25 November 2021, Accepted 25 February 2022, Published 27 February 2022 


\section{PENDAHULUAN}

Anak usia dini adalah anak yang berusia dengan rentang 0 hingga 6 tahun yang mana sedang mengalami masa perkembangan yang sangat pesat. Menurut Permendikbud (2014) menyatakan bahwa usia dini adalah periode anak menjalani kehidupannya dengan waktu cukup banyak untuk bermain. Anak usia dini adalah anak yang berusia yang berkisar 0-6 tahun yang sedang berlangsung masa keemasan memiliki karakteristik yang unik serta berbeda-beda tiap anak (Husin \& Yaswinda, 2021). Usia dini biasanya diartikan sebagai usia penentu dan pondasi awal agar anak memiliki kesiapan dan keberhasilan dalam proses belajar untuk masa selanjutnya (Rosiyanah, Yufiarti, 2021). Jadi dapat disimpulkan bahwa anak usia dini merupakan usia lahir hingga 6 tahun yang sedang mengalami tumbuh kembang secara pesat dan memiliki perbedaan karakteristik yang unik. Agar terstimulasinya seluruh aspek pertumbuhan dan perkembangan pada anak usia dini, maka perlu diberikan pendidikan di usianya yaitu pendidikan untuk anak usia dini. Pendidikan yang diselenggarakan pada anak usia dini umumnya disebut dengan Pendidikan Anak Usia Dini atau disingkat dengan sebutan PAUD. Pembelajaran di PAUD diberikan melalui kegiatan yang menyenangkan serta mengandung unsur-unsur bermain. Pendidikan Anak Usia Dini bertujuan untuk memberikan stimulasi terhadap perkembangan anak, kemampuan, keterampilan, maupun kecerdasan pada anak usia dini. Pada masa inilah merupakan masa yang paling tepat dalam mengembangkan seluruh potensi yang dimiliki anak. Hasil dari sebuah penelitian bahwa jika anak kurang diberikan sentuhan ataupun rangsangan (stimulasi) seeperti visual, verbal maupun taktil dan kinetetik maka perkembangan pada otak hanya mencapai $20 \%$ sampai dengan 30\% lebih kecil dari ukuran normal sesuai usianya (Hikam \& Nursari, 2020). Berdasarkan Standar Nasional Pendidikan PAUD menjabarkan bahwa "tingkat pada pencapaian perkembangan anak merupakan proses tumbuh kembang anak yang terjadi pada umur tertentu" Nuh (2014) dalam (Ni Made Ayu Suryaningsih, 2018).

Pada masing-masing anak terlahir dengan kemampuan maupun kecerdasan yang memang ada dan berbeda-beda antara anak satu dengan anak yang lainnya. Namun, kecerdasan yang dimiliki oleh setiap anak tidak hanya cersdas secara otak saja atau yang biasa disebut dengan IQ (Intelligences Quotient) akan tetapi juga terdapat kecerdasan lainnya. Tokoh ahli bernama Howard Gardner yang menciptakan teori multiple intelligences (kecerdasan jamak). Pada teori tersebut, ternyata kecerdasan tidak hanya berhubungan dengan kecerdasan otak saja melainkan berbagai macam kecerdasan. Teori kecerdasan jamak ini umumnya digunakan oleh pendidik agar dapat meningkatkan seluruh potensi yang dimiliki oleh anak (S. Aisyah, 2014). Berdasarkan teori kecerdasan jamak (Multiple Intelligences) yang merupakan teori yang menjelaskan bahwa manusia memiliki kecerdasan yang terdiri dari banyak kecerdasan yang sangat membutuhkan stimulasi yang tepat dan optimal sehingga dapat berkembang dengan baik. Kecerdasan jamak tersebut meliputi: kecerdasan logika matematika, kecerdasan bahasa, kecerdasan visual spasial, kecerdasan kinestetik, kecerdasan musikal, kecerdasan interpersonal, kecerdasan intrapersonal, kecerdasan naturalis, dan kecerdasan eksistensial (E. N. Aisyah, 2014). Pengembangan kecerdasan jamak tersebut merupakan salah satu upaya untuk menanamkan kesiapan kepada anak sejak usia dini agar memiliki pondasi yang kokoh dalam menghadapi kehidupan selanjutnya (Jamaris, 2014). Pengembangan ini dilaksanakan pada proses pembelajaran. Pembelajaran yang menggunakan menitikberatkan pada multiple intelligences merupakan sebagai bentuk ushaa agar dapat memberikan pengalaman belajar kepada anak yang disesuaikan dengan kebutuhan, gaya belajar anak, kognisi, dan inteligensi anak (Mustajab et al., 2020).

Menurut Jamaris (2014) kecerdasan naturalis merupakan salah satu bagian dari multiple intelegences yang berhubungan dengan kepekaan terhdap lingkungan alam sekitar. Pada saat anak berusia 4-5 tahun dapat dilihat wujud dari kecerdasaan anak yang memiliki kecerdasan naturalis ini seperti berikut: (1) anak menyukai kegiatan yang berkenaan dengan lingkungan sekitar contohnya menyukai hewan dengan cara memelihara, menyukai tanaman, (2) memperlihatkan keinginan untuk menjaga kelestarian di lingkungan sekitarnya, (3) peka 
dengan kejadian alam, (4) menyukai eksplorasi atau menjelajahi dengan cara mengamati bagaimana lingkungan sekitarnya.

Pembelajaran yang dilaksanakan di sekolah untuk anak usia dini harus berlandaskan kepada prinsip pembelajaran maupun karakteristik pembelajaran. Pembelajaran di TK mengutamakan proses pembelajaran yang berfokus pada segala aspek yang terdapat pada anak usia dini. Pembelajaran yang lebih mengutamakan pada anak artinya memberikan kesempatan yang banyak untuk anak belajar dengan pengalamannya sendiri. Pembelajaran di TK bukan hanya bertujuan untuk menstimulasi perkembangan anak saja akan tetapi juga termasuk dengan kecerdasan yang dimiliki oleh setiap anak.

Kegiatan yang diterapkan di TK diharapkan pendidik yang mampu menguasai dalam membimbing anak belajar. Kegiatan yang dilaksanakan diantaranya sebagai berikut: (1) penyediaan lingkungan, lingkungan kondusif bagi perkembangan dan belajar anak. Lingkungan yang dimaksudkan yaitu baik fisik maupun non fisik, indoor maupun outdoor, (2) mendidik dan mengajar merupakan kegiatan pengembangan melalui pendidikan yang dimaksudkan untuk menanamkan nilai-nilai seperti nilai moral dan nilai agama secara optimal, (3) kegiatan membimbing secara tepat, kegiatan ini dimaksudkan untuk memberikan penanganan terhadap masalah yang dialami oleh anak namun permasalahan tersebut akan lebih baik apabila dilakukan secara pesuasif (Ali Nugraha, Dadang Sukirman, Rudianto, 2014).

Kegiatan yang diterapkan di TK bertujuan untuk menstimulasi potensi yang dimiliki anak. Sedangkan kegiatan pengembangan merupakan serangkaian kegiatan sebagai fasilitasi terhadap perkembangan dan belajar anak TK. Secara umumnya, kegiatan tersebut meliputi penyediaan lingkungan kondusif terhadap perkembangan dan belajar anak, membentuk perilaku anak dengan kegiatan mendidik dan mengajar, serta membantu memecahkan permasalahan yang dihadapi anak dengan memberikan arahan yang tepat.

Berdasarkan pengamatan yang dilaksanakan bahwa anak kurang bebas dalam melakukan aktivitas yang mana sedang berada pada masa pandemi, orang tua lebih sering memberikan sesuatu yang praktis untuk anak bermain seperti gadget. Orang tua lebih mengutamakan kecerdasan yang berfokus pada otak saja namun dasarnya banyak kecerdasan yang seharusnya diberikan stimulasi. Jadi, hal tersebut membuat anak kurang bebas dalam menentukan aktivitas bermain yang anak inginkan dan butuhkan di alam yang bebas. Disamping itu, sarana dan prasarana yang terbatas sehingga proses pembelajaran untuk membangun kecerdasan anak terutama kecerdasan naturalis kurang terstimulasi. Secara umum guru lebih mengutamakan kesiapan untuk memasukan jenjang pendidikan dasar seperti membaca, menulis, maupun berhitung. Hal tersebut, mengakibatkan anak kurang peduli maupun mengenal lingkungan sekitarnya seperti makhluk hidup dan mati.

Sains berasal dari bahasa latin yakni Scientia yang bermakna "saya tahu". Sains juga bisa diartikan sebagai ilmu yang mempelajari sebab akibat yang ditimbulkan dari suatu keadaan yang sedang terjadi di alam sekitar (Rahmah, 2019). Salah satu kegiatan yang dapat menstimulasi kecerdasan naturalis pada anak usia dini, yaitu kegiatan life science (sains kehidupan). Sains yang akan diberikan untuk anak berupa tujuh cabang sains salah satunya life science yang merupakan cabang dari sains (Halimatus, Lara Fridani, 2020). Pembelajaran yang berkenaan dengan sains lebih berfokus pada pemberian pengalaman kepada anak secara langsung dan lebih nyata. Pembelajaran tersebut tidak hanya berasal dari anak saja akan tetapi guru juga harus memberikan motivasi dan membimbing anak dengan optimal agar mendapatkan pengalaman sains (Yaswinda, 2018). Sains dalam artian singkatnya merupakan suatu aktivitas yang memberikan kesempatan untuk anak agar dapat mengeksplorasi, mengajukan pertanyaan, dan belajar mengenali lingkungan sekitarnya. Pada hasil dari kegiatan sains yang telah dilalui dengan proses sains pula maka menghasilkan kenangan yang berkesan, tidak mudah dilupakan, dan juga dapat digunakan sebagai bentuk pemecahan masalah yang akan dihadapi (Bundu, 2013; Farida, 2021). 
Sains yang diberikan untuk anak usia dini Life Scince (sains kehidupan) diartikan sebagai pengenalan terhadap makhluk hidup seperti tumbuhan dan hewan sekitar. Tujuan dari pengenalan tersebut untuk mengetahui bagaimana proses makhluk hidup berhubung satu sama lain dan sekitar (Muktia Pramitasari, Elindra Yetti, 2018). Berdasarkan National Science Educational Standard, menjelaskan bahwa Life science merupakan sebuah pengetahuan yang mempelajari tentang tanaman, hewan, dan manusia. Lingkup pembelajaran life science yang diberikan untuk anak TK adalah bagaimana mengenal karakteristik makhluk hidup, mengenal perbedaan dari tumbuhan sekitar dan hewan sekitar. Sehingga ruang lingkup dari life science pada anak usia dini dirangkum dengan kegiatan pengenalan makhluk hidup dan benda mati dengan cara membedakannya, membedakan hewan dengan ciri-cirinya dan cara perkembangbiakannya, dan mengetahui karakteristik tumbuhan dengan cara menyebutkan bagian dari tumbuh-tumbuhan serta mengurutkan proses pertumbuhan tumbuhan tersebut (Asih Mukharoh, Siti Wahyuningsih, 2016).

Sains biologi, atau yang disebut sebagai "life science", adalah bagian dari sains permulaan yang diberikan kepada anak-anak sejak lahir hingga usia 8 tahun. Pada Standar Tingkat Pencapaian Perkembangan Anak atau STTPA bahwa sains biologi salah satu dari sedikit mata pelajaran yang secara eksplisit terkait dengan perkembangan kognitif anak. Ternyata life science ini membahas tentang fakta, konsep, teori, prinsip, dan aturan yang berhubungan dengan hewan, tumbuhan, hubungan antara tumbuhan dan hewan, serta unsur-unsur dari kehidupan dengan lingkungannya (Subhan, 2016).

Kegiatan pembelajaran yang mengggunakan pendekatan berkenaan dengan science (sains) pada anak memiliki peranan penting sebagai hubungan antara kerja otak dengan informasi secara faktual untuk mencapai kebermaknaan dalam menguasai konsep (Fardiah, Santosa Murwani, 2020). Kegiatan life science ini lebih berfokus pada salah satu hewan saja yaitu, ikan cupang. Ikan cupang merupakan salah satu jenis ikan hias yang dapat menarik rasa ingin tahu anak untuk mengenalnya serta memeliharanya. Menurut (Darna Susantie, Usy N. Manurung, 2018) bahwa ikan cupang memiliki keunikan tersendiri yaitu kemenarikan yang ditimbulkan dari warna pada bagian tubuhnya.

Dari pernyataan Rocmah (2016), dapat disimpulkan kecerdasan naturalistik anak dapat terlihat ketika mereka mampu mengenali perbedaan antara kehidupan sehari-hari mereka dengan orang tua, kakek-nenek mereka, dan juga benda mati. Saat seorang anak menyadari perbedaan antara kehidupan normal dan kehidupan benda mati, adalah mungkin untuk melihat bahwa seorang anak memiliki kemampuan alami untuk membedakan yang benar dan yang salah.

Dari adanya penjelasan tersebut, seharusnya anak yang sudah berusia 5-6 tahun sudah memiliki kecerdasan naturalis yang sesuai dengan indikator. Berdasarkan penjelasan tersebut maka dilaksanakanlah penelitian tentang stimulasi kecerdasan naturalis anak berusia 5-6 tahun melalui kegiatan life science.

\section{METODOLOGI}

Penelitian ini dilakukan di Taman Kanak-Kanak Kasih Bunda Takwa Sungai Sirah yang terletak di Provinsi Sumatera Barat Kabupaten Pesisir Selatan. Penelitian ini menggunakan metodologi penelitian deskriptif kualitatif. Fokus penelitian ini adalah naturalis anak usia 5 sampai 6 tahun. Sedangkan teknik pengambilan sample dengan metode simple random sampling, pangambilan sampel didasarkan pada sampel yang diambil dari suatu populasi tanpa memperhatikan besar kecilnya populasi tersebut. Metode penelitian ini bertujuan untuk menjabarkan dan menjelaskan secara rinci permasalahan yang terjadi pada suatu kelompok tertentu.

Jika sudah ditetapkan metode pengumpulan data, maka selanjutnya melakukan penyusunan instrument pengumpulan data. Tujuan instrumen ini adalah untuk memudahkan pengumpulan data yang membahas tentang kecerdasan naturalis anak berusia 5-6 tahun di Taman Kanak-Kanak Kasih Bunda Takwa Sungai Sirah. Istrumen ini divalidasi 
oleh pakar ahli di bidangnya. Saat proses pengumpulan data telah dilaksanakan maka tahapan selanjutnya adalah teknik analisis data. Analisis data yang dilakukan dengan caraa analisis deskriptif kualitatif. Penggunaan analisis data deskriptif kualitatif ini digunakan untuk menganalisis hasil pengumpulan data observasi dan wawancara. Gamabr 1 disajikan gambaran dari alur penelitian berdasarkan bagan.
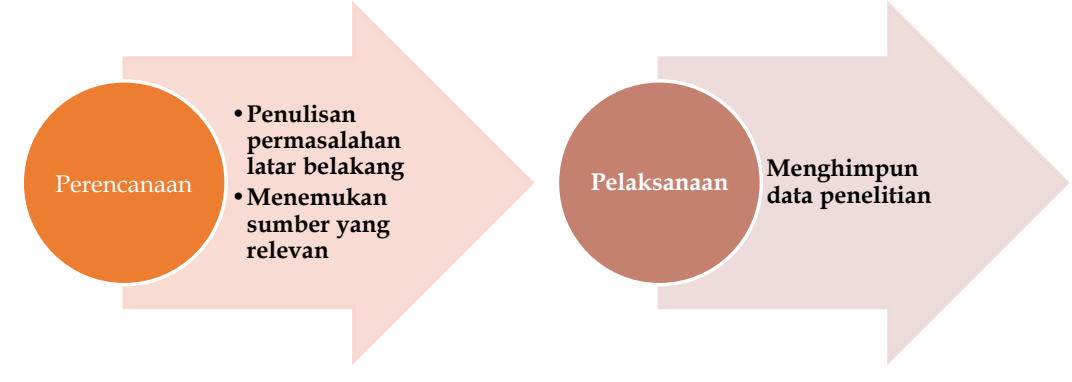

Bagan 1. Alur Penelitian

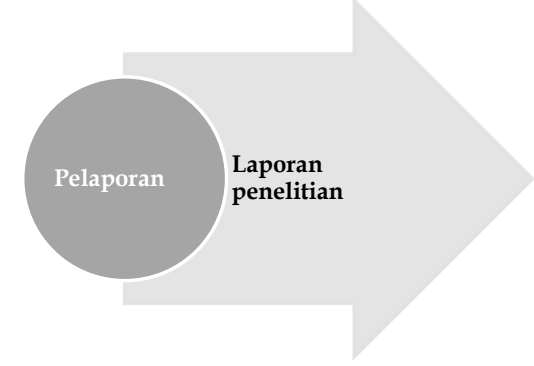

\section{HASIL DAN PEMBAHASAN}

Dari hasil penelitian yang didapatkan pada proses pengumpulan data yaitu pada objek penelitian kecerdasan naturalis anak berusia 5-6 tahun di TK Kasih Bunda Takwa Sungai Sirah. Didapatkan hasil bahwa kecerdasan naturalis anak semakin terlihat saat anak melakukan kegiatan life science dengan ikan cupang. Kegiatan life science dilaksanakan berdasarkan tahap-tahapnya. Awal kegiatan life science ini, guru memperkenalkan pelaksanaan yang mengajarkan anak untuk mencari sendiri terkait fakta dan juga sebuah konsep sederhana. Adapun rumusan indikator pada kegiatan life science ini adalah sebagai berikut: mengklasifikasikan tumbuhan dengan dedaunan yang kering dan hijau, mengklasifikasikan berdasarkan bentuk dari dedaunan tumbuhan sekitar, mengklasifikan tumbuhan yang dapat berbuah dan berbunga, mengklasifikasikan ranting tumbuhan berdasarkan ukuran. Hasil penilaian guru terhadap capaian anak disajikan pada tabel 1.

Tabel 1. Hasil Penilaian Guru Terhadap Capaian Anak

\begin{tabular}{|llcccc}
\hline No & \multicolumn{1}{c}{ Indikator Pencapaian Naturalistik } & \multicolumn{2}{c}{ Hasil Pencapaian } & Jumlah \\
& \multicolumn{1}{c}{ Bnak }
\end{tabular}

Keterangan:

BB : Belum Berkembang

MB : Mulai Berkembang

BSH : Berkembang Sesuai Harapan

BSB : : Berkembang Sangat Baik

Pada tahapan pertama, guru memperkenalkan kepada anak tentang tumbuhan dari lingkungan sekitar kemudian memberikan contoh dalam mengklasifikasikan berbagai bentuk tumbuhan. Kemudian, guru memberikan kesempatan kepada siswa untuk melakukan penelitian lapangan (bereksplorasi) di luar kelas sehingga siswa merasa nyaman melakukan eksperimen life science di sekitar kelas. Pelaksanaan indikator pertama pelaksanaan kegiatan 
life science yaitu mengklasifikasikan tumbuhan dengan dedaunan kering dan hijau. Anak diberi kesempatan untuk mengenal terlebih dahulu tumbuhan yang ada di lingkungannya. Setelah anak mengenal dan mengetahui tumbuhan tersebut, guru memberikan arahan dan bimbingan dalam menyelesaikan tugas mencari dan menemukan tumbuhan dengan deudanan yang kering dan juga hijau. Setelah anak menyelesaikan perintah dan tugas dari guru anak diminta untuk mengumpulkannya di hadapan guru. tugas guru disini adalah guru mempertanyakan hasil kerja anak dalam mengklasifikasikan tumbuhan deudanan tersebut. Satu persatu dari anak diminta untuk menjelaskannya di hadapan teman-teman lainnya. Dalam proses ini, anak begitu bersemangat menyebutkan dan percaya diri. Anak menunjukkan rasa ingin tahunya terhadap tumbuhan tersebut dengan mengungkap pertanyaan yang ada dipikirannya.

Selanjutnya, indikator kedua kegiatan life science yaitu mengklasifikasikan berdasarkan bentuk dari dedaunan tumbuhan di sekitar. Anak diberi kesempatan mengamati dan menemukan dedaunan yang sama warnanya, yang sama bentuknya atau kemiripannya, dan yang sama jenisnya misalnya dedaunan buah mangga dan deudaunan rumput. Setelah anak dapat mengamati dan menemukannya, seluruh anak dikumpulkan kemudian guru memberikan bimbingan dan arahan untuk menggali pengetahuan anak tentang apa tugas yang diselesaikannya. Tahapan selanjutnya yaitu indikator kegiatan ketiga, yaitu mengklasifikasikan tumbuhan berbunga dan berbuah. Anak dibagai dalam beberapa kelompok kemudian, anak diminta untuk mengumpulkan sebanyaknya tumbuhan yang ada bunganya begitu pun tumbuhan yang tidak ada bunganya. Anak terlihat sangat antusias dalam menemukan tumbuhan tersebut sepertinya anak menyukai kegiatan yang melibatkan mereka dengan lingkungan sekitarnya. Anak lebih menjadi peduli terhadap tumbuhan di sekelilingnya.

Setelah dilaksanakan indikator tahapan ketiga, dilanjutkan dengan indikator tahapan keempat yaitu mengklasifikasikan ranting tumbuhan berdasarkan ukurannya. Anak diminta untuk mengumpulkan ranting-ranting yang ada di halaman sekolah tanpa mematahkan ranting pada tumbuhan hal ini bertujuan untuk mengenalkan bahwa tumbuhan tidak hanya terdapat dedaunan, buah, mampun batang saja akan tetapi tumbuhan juga memiliki rantingranting yang dapat menopang pertumbuhan sebuah tumbuhan. Selain itu, agar anak memiliki rasa peduli dan menjaga lingkungan dari dedaunan, buah, dan ranting yang berjatuhan agar dibersihkan kemudian di buang pada tempatnya.

Pada hasil temuan penelitian sebelumnya, yang dilaksanakan oleh (Riska Aprilianti, 2021) yang membahas tentang peningkatan kecerdasan naturalis dengan menggunakan pendekatan saintifik. Hasil temuan ini menjelaskan bahwa melalui pendekatan saintifik dapat memberikan peningkatan terhadap kecerdasan naturalis anak. Penelitian ini memiliki perbedaan dan keterbaruan dari temuan sebelumnya yaitu pada kegiatan yang diberikan, penelitian saat ini menggunakan kegiatan life science sedangkan temuan sebelumnya melakukan dengan sebuah pendekatan yakni saintifik. Selanjutnya penelitian oleh (Wulan, 2021) yang membahas tentang kecerdasan naturalis yang ditingkatkan melalui media realia. Hasil temuan ini menunjukkan sebelum diberikan perlakuan menggunakan media realia hasil kecerdasan naturalis anak masih dibawah target pencapaian yakni 32,81\% kemudian setelah dilakukan tindakan atau perlakuan mengalami peningkatan sedikit yakni 37, 44\% dan dilanjutkan dengan tindakan yang sama namun pada waktu yang berbeda hasilnya didapatkan $70,25 \%$ menjadi $88,16 \%$. Berdasarkan hasil tersebut, bahwa menggunakan media realia juga dapat memberikan peningkatan terhadap kecerdasan naturalis anak usia dini. Perbedaan penelitian ini dengan penelitian sebelumnya adalah media yang diberikan dan kegiatan yang dilakukan. Penelitian sebelumnya menggunakan media realia, sedangkan penelitian ini melakukan kegiatan life science. Selanjutnya juga terdapat penelitian yang dilakukan oleh (Zellawati, 2017) mengenai pemberian stimulasi kecerdasan naturalistik dengan pendidikan cinta kelautan. Hasil temuan ini adalah peningkatan kecerdasan naturalis anak dapat dilakukan oleh guru maupun orang tua dengan pembentukan melalui lingkungan 
sekitar anak salah satunya mencintai lingkungan kelautan. Jadi. Berdasarkan analisis dari beberapa penelitian terdahulu maka dapat disimpulkan bahwa penelitian ini memiliki perbedaan dan keterbaruan yakni pelaksanaan kegiatan life science terhadap kecerdasan naturalistic anak usia dini.

Berdasarkan kegiatan tersebut, terlihat anak sangat menikmati dan bersemangat mengikuti proses pembelajaran serta anak menjadi tertarik untuk menjaga lingkungan sekitarnya dengan cara merawat dan membersihkan. Dengan adanya kegiatan life science ini membentuk kecerdasan terutama kecerdasan naturalis anak yang saat ini jarang diberikan stimulasi sejak usia dini. Hal ini sangat berkaitan dengan indikator pada kecerdasan naturalis pada anak usia dini

\section{SIMPULAN}

Adanya peningkatan pada kecerdasan naturalistik anak di TK Kasih Bunda Taqwa Sungai Sirah. Kegiatan life science dapat dilakukan untuk peningkatan kecerdasan naturalistik anak. Hasil penelitian ini, diharapkan kepada sekolah agar dapat menggunakan kegiatan life science ini untuk peningkatan kecerdasan lainnya.

\section{UCAPAN TERIMA KASIH}

Terutama dan utama peneliti ucapkan terima kasih kepada Allah Subhanu wa Ta'ala yang telah memberikan kenikmatan dan kelancaran pada proses penelitian. Selanjutnya peneliti ucapkan terima kasih yang sebesar-besarnya kepada kepala sekolah Taman Kanakkanak Kasih Bunda Taqwa, Sungai Sirah. Juga kepada keluarga yang selalu memberikan doa dan dukungan penuh dalam menyelesaikan penelitian ini.

\section{DAFTAR PUSTAKA}

Aisyah, E. N. (2014). Inovasi Media Pembelajaran Bagi Kecerdasan Jamak Anak Taman KanakKanak. Jurnal PAUD, 1(3).

Aisyah, S. (2014). Pembelajaran Terpadu (1st ed.). Universitas Terbuka.

Ali Nugraha, Dadang Sukirman, Rudianto, S. B. (2014). Kurikulum dan Bahan Ajar di TK (1st ed.). Universitas Terbuka.

Asih Mukharoh, Siti Wahyuningsih, Y. S. (2016). Efek Quantum Learning Terhadap Kemampuan Life Science Anak Usia 5-6 Tahun TK BA Aisyiah Polokarto Sukoharjo. Jurnal FKIP UNS, 4(3).

Darna Susantie, Usy N. Manurung, I. O. K. K. (2018). Tingkah Laku Ikan Cupang (Beta Splendes) Terhadap Pakan Yang Berbeda. Jurnal Ilmiah Tindalung, 4(2). https://doi.org/https://doi.org/10.5281/jit.v4i2.142

Fardiah, Santosa Murwani, N. D. (2020). Meningkatkan Kemampuan Kognitf Anak Usia Dini Melalui Pembelajaran Sains. Jurnal Obsesi : Jurnal Pendidikan Anak Usia Dini, 4(1). https://doi.org/10.31004/obsesi.v4i1.254

Farida, N. (2021). Stimulasi Keterampilan Proses Sains Anak Melalui Model Pembelajaran Sains Berbasis Proyek. Mitra Ash-Shibyan: Jurnal Pendidikan Dan Konseling, 4(1). https://doi.org/10.46963/mash.v4i01

Halimatus, Lara Fridani, S. M. M. (2020). Pengembangan Media Grafis untuk Pengenalan Life Science Pada Anak Usia Dini. Jurnal Obsesi : Jurnal Pendidikan Anak Usia Dini, 4(1). https://doi.org/10.31004/obsesi.v4i1.318

Hikam, F. F., \& Nursari, E. (2020). Analisis Penggunaan Metode Eksperimen Pada Pembelajaran Sains Bagi Anak Usia Dini. Murhum : Jurnal Pendidikan Anak Usia Dini, 1(2), 38-49. https://doi.org/10.37985/murhum.v1i2.14

Husin, S. H., \& Yaswinda, Y. (2021). Analisis Pembelajaran Sains Anak Usia Dini di Masa $\begin{array}{lllll}\text { Pandemi Covid-19. Jurnal } & \text { Basicedu, } & \text { 5(2), } & \text { 581-595. } \\ \text { https://doi.org/10.31004/basicedu.v5i2.780 }\end{array}$ 
Jamaris, M. (2014). Pengembangan Instrumen Baku Kecerdasan Jamak Anak Usia Dini. Parameter: Jurnal Pendidikan Universitas Negeri Jakarta, 25(2), 123-137. https:// doi.org/10.21009/parameter.252.08

Muktia Pramitasari, Elindra Yetti, H. (2018). Pengembangan Media Sliding Book Untuk Pengenalan Sains Kehidupan (Life Science) Kelautan Untuk Anak Usia Dini. Jurnal Pendidikan Anak Usia Dini, 12(2). https:// doi.org/10.21009/JPUD.122

Mustajab, M., Baharun, H., \& Iltiqoiyah, L. (2020). Manajemen Pembelajaran melalui Pendekatan BCCT dalam Meningkatkan Multiple intelligences Anak. Jurnal Obsesi : Jurnal Pendidikan Anak Usia Dini, 5(2), 1368-1381. https:// doi.org/10.31004/obsesi.v5i2.781

Ni Made Ayu Suryaningsih, N. L. R. (2018). Implementation of Game-Based Thematic Science Approach in Developing Early Childhood Cognitive Capabilities. Jurnal Obsesi: Jurnal Pendidikan Anak Usia Dini, 2(2), 194-201. https://doi.org/10.31004/obsesi.v2i2.90

Permendikbud. (2014). Kurikulum 2013 Pendidikan Anak Usia Dini.

Rahmah, R. (2019). Persepsi Guru Tentang Pembelajaran Sains Anak Usia 5-6 Tahun Di Gugus Ii Melati Kecamatan Simpang Tiga Pekanbaru. Kindergarten: Journal of Islamic Early Childhood Education, 1(2), 89. https:// doi.org/10.24014/kjiece.v1i2.6656

Riska Aprilianti, S. S. (2021). Meningkatkan Kecerdasan Naturalis Anak Usia 5-6 Tahun Melalui Pendekatan Saintifik. Jurnal Golden Age, Universitas Hamzanwadi, 5(1), 393407.

Rosiyanah, Yufiarti, S. M. M. (2021). Pengembangan Media Stimulasi Sensori Anak Usia 4-6 Tahun Berbasis Aktivitas Bermain Tujuh Indera. Jurnal Obsesi: Jurnal Pendidikan Anak Usia Dini, 5(1), 941-957. https://doi.org/10.31004/obsesi.v5i1.758

Subhan. (2016). Peningkatan Pemahaman Sains Biologi Melalui Permainan Karambol. Jurnal Pendidikan Anak Usia Dini, 10(1). https:// doi.org/10.21009/JPUD.101.08

Wulan, D. S. A. (2021). Peningkatan Kecerdasan Naturalis Melalui Media Relia di TK Al Hidayah Kabupaten Langkat. Jurnal Usia Dini, 7(1). https:// doi.org/10.24114/jud.v7i1.25650

Yaswinda, Y. (2018). Pelaksanaan Model Pembelajaran Sains Berbasis Multisensori-Ekologi Di Taman Kanak-Kanak Aisyiyah 6 Kota Padang. Pedagogi: Jurnal Ilmu Pendidikan, 17(2), 18. https:// doi.org/10.24036/fip.100.v17i2.271.000-000

Zellawati, A. (2017). Mengasah Kecerdasan Naturalistik Melalui Pendidikan Cinta Kelautan Pada Anak Usia Dini. Jurnal Saintek Maritim, XVII(1), 99-109. https://doi.org/10.33556/jstm.v0i1.162 